\title{
Perancangan Sistem Informasi Radio Online Universitas Nasional Berbasis Web
}

\author{
Ibnu Bukhari, Moh. Iwan Wahyuddin, Novi Dian Nathasia* \\ Fakultas Teknologi Komunikasi dan Informatika, Universitas Nasional, Jakarta, Indonesia \\ Email: 1ibnubukhari17@gmail.com, ${ }^{2}$ iwan_wyd@yahoo.com, ${ }^{3}$ novidian@civitas.unas.ac.id \\ Email Penulis Korespondensi: novidian@civitas.unas.ac.id
}

\begin{abstract}
Abstrak-Radio di suatu perguruan tinggi kini telah berkembang cukup pesat. Radio Unas adalah salah satu siaran radio yang dimiliki oleh Universitas Nasional yang di kelola Laboratorium TV dan Radio Unas. Kini hadir radio online atau radio streaming berbasis website. Radio streaming merupakan teknologi yang mengirim file audio secara bersamaan pada banyak pengguna. Tujuan dari penelitian ini adalah membangun dan mengembangkan radio online Universitas Nasional dengan menggunakan Icecast sebagai freeware streaming radio dan winamp sebagai perangkat lunak yang digunakan untuk media penyiaran radio. Perancangan sistem informasi ini melalui beberapa tahapan diantaranya adalah analisis kebutuhan, perancangan sistem, pengujian dan implementasi. Dengan adanya radio streaming di Universitas Nasional, masyarakat dan mahasiswa Universitas Nasional tidak ketinggalan informasi terkini mengenai Universitas Nasional serta menjadi sarana hiburan bagi mahasiswa Universitas Nasional dan masyarakat selama terhubung dengan internet. Dari hasil uji coba dari website radio online Universitas Nasional adalah sistem radio streaming dapat membantu masyarakat serta mahasiswa Universitas Nasional untuk menampilkan konten radio streaming, mendengarkan music serta melihat kegiatan dari Radio Universitas Nasional melalui website.
\end{abstract}

Kata Kunci: Perancangan, Radio, Streaming, Website

\begin{abstract}
Radio in a college has now developed sufficiently. Radio Unas is a radio broadcast owned by the National University that is managed by the Unas TV and Radio Laboratory. Present online radio or website based radio streaming. Radio streaming is a technology that sends audio files simultaneously to many users. The purpose of this research is to build and develop a National University online radio using Icecast as a freeware and winamp streaming radio as software used for radio broadcast media. The design of this information system through several discussions is a needs analysis, system design, testing and implementation. With streaming radio at the National University, the public and students of the National University do not miss the latest information about the National University and become a means of entertainment for National University students and the public as long as they are connected to the internet. From the trial results of the National University's online radio site, the streaming radio system can help the public and students of the National University to provide streaming radio content, listen to music and view activities from the National University Radio through the website.
\end{abstract}

Keywords: Design, Radio, Streaming, Website

\section{PENDAHULUAN}

Di era revolusi seperti sekarang ini perkembangan teknologi mengalami kemajuan yang sangat pesat[1]. Kemudahan dalam mengakses informasi pada era ICT (Information and Communication Technology) sudah membuktikan bahwa saat ini informasi bisa diakses dimanapun dan kapanpun saat dibutuhkan[2]. Salah satu teknologi yang berkembang untuk mengakses dan menyampaikan informasi adalah radio[3]. Kini radio tidak lagi menjadi media lokal yang mempunyai keterbatasan wilayah dan geografis[4]. Sekarang radio sudah bisa didengarkan siapa saja dan dimana saja melalui teknologi radio streaming via internet yang bertujuan supaya bisa diakases oleh para pendengar radio yang lokasinya tidak dapat menangkap siaran radio[5]-[6]. Dengan memanfaatkan teknologi radio streaming akan menjembatani para pendengar radio sehingga tidak ada lagi keterbatasan dalam jaringan jangkauan siaran radio[7]. Radio streaming ini tidak menggunakan frekuensi gelombang radio, melainkan dengan menggunakan koneksi internet sebagai pengganti gelombang radio [8]. Radio streaming sama halnya dengan radio biasa yang siarannya bisa di dengar oleh banyak pendengar, hanya saja dengan menggunakan radio straming pendengar bisa mendengar radio kapanpun dan dimanapun selama terhubung dengan internet[9].

Pada penelitian sebelumnya [4] [9] dan [12] telah dibuat aplikasi radio streaming menggunakan winamp dan shoutcast sebagai sebagai software untuk melakukan siaran radio. Untuk server radio menggunakan Shoutcast DNAS tetapi masih mengalami delay dalam melakukan siaran. Maka dalam penelitian ini akan mengembangkan radio online dengan memakai server streaming yang berbeda untuk mengatasi delay dan menambahkan fitur menu crew yang akan menampilkan struktur organisasi dari Radio Universitas Nasional. Serta menambah fitur jadwal siaran sehingga pengunjung tahu kapan harus mendengarkan siaran radio Universitas Nasional.

Atas dasar inilah dibuat maka sistem informasi radio online Universitas Nasional. Untuk membuat aplikasi radio online membutuhkan hardware dan software. Untuk hardware adalah seperangkat komputer dan jaringan internet. Sedangkan software menggunakan Winamp dan edcast untuk membantu dalam melakukan siaran radio. Serta icecast sebagai server streaming radio. Dengan adanya sistem informasi radio online Universitas Nasional akan memudahkan masyarakat dan mahasiswa Universitas Nasional untuk mendapatkan informasi terkini mengenai kampus serta sebagai media suara edukasi dan juga hiburan. Berdasarkan uraian 
Available Online at https://ejurnal.stmik-budidarma.ac.id/index.php/mib DOI 10.30865/mib.v4i3.2214

singkat di atas, maka dapat diangkat sebuah judul penelitian "Sistem Informasi Radio online Unviersitas Nasional Berbasis Web".

\subsection{Streaming}

\section{METODOLOGI PENELITIAN}

Streaming merupakan penggunaan file video atau audio secara bersamaan di beberapakomputer dengan prerecord dari sebuah mesin server(web server). Proses pengiriman data dalam streaming dilakukan secara broadcast melalui jaringan internet yang kemudian di tampilkan oleh aplikasi pada komputer atau smartphone [10]-[11].

\subsection{Icecast}

Icecast merupakan sebuah server gratis untuk melakukan streaming audio melalui internet. Icecast digunakan untuk membuat radio online atau radio streaming. Icecast memiliki fitur yang sangan mudah ditambahkan dan mendukung standard terbuka untuk melakukan interaksi sehingga memudahkan pendengar untuk mengaksesnya. Icecast mempunyai dukungan untuk streaming audio secara simultan, artinya setiap aliran memiliki "mount point" sehingga pengguna bisa mengaksesnya melalui URL jaringan[2].

\subsection{Winamp}

Winamp merupakan sebuah software sebagai pemutar multimedia yang digunakan untuk memainkan file audio maupun video streaming [9].

\subsection{Perancangan Usecase Diagram}

Berikut adalah usecase diagram radio streaming Universitas Nasional.

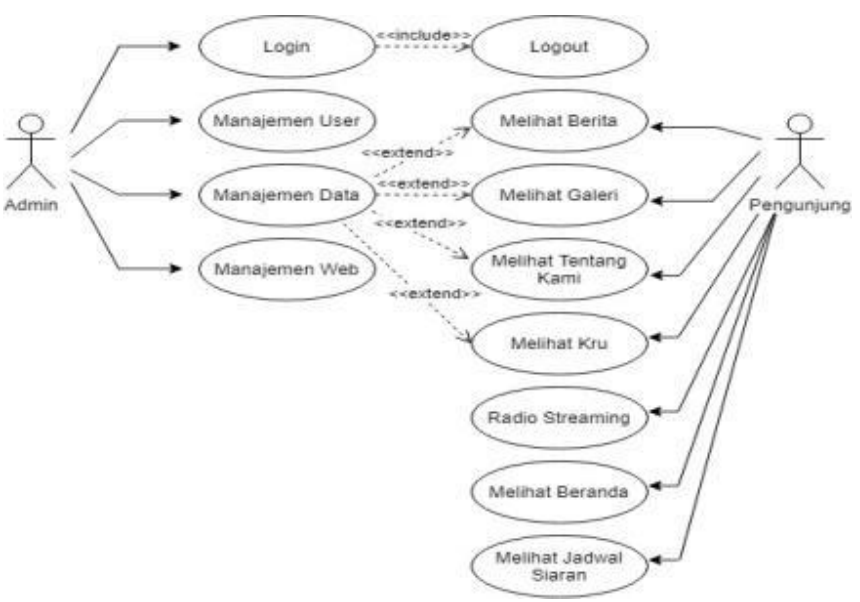

Gambar 1. Perancangan Use Case Diagram

Pada gambar 1 adalah usecase sistem informasi radio online Universitas Nasional. Saat membuka website, pengguna akan dihadapkan dengan pilhan menu yaitu Beranda, Berita, Galeri, Profil, Crew dan Tentang kami. Sedangkan untuk admin akan menampilkan menu user, galeri, Crew dan berita. Admin akan memanejemen mengenai isi berita, crew dan galeri untuk ditampilkan ke dalam website.

1. Beranda : Akan menampilkan slider berupa informasi terkini, dan dibawah slider ada button play untuk mendengarkan siaran radio.

2. Berita : menampilkan berita terkini mengenai radio Universitas Nasional.

3. Galeri : Berisi dokumentasi mengenai kegiatan yang di lakukan radio Universitas Nasional.

4. Crew : Menampilkan struktur organisasi radio Universitas Nasional.

5. Tentang Kami : Berisi profil mengenai radio Universitas Nasional.

6. Jadwal Siaran : Menampilkan Jadwal siaran langsung radio Universitas Nasional.

\subsection{Diagram Alur Perancangan Radio Streaming}

Untuk tercapainya tujuan, sebuah penelitian di perlukan tahapan penelitian supaya penelitian menjadi sistematis. Tahapan atau diagram alir dapat dilihat pada gambar 2. 


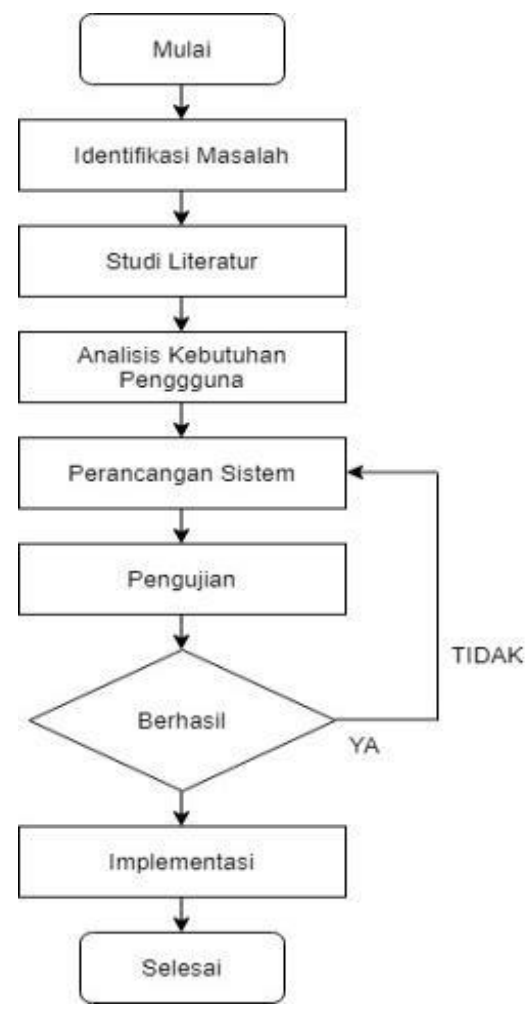

Gambar 2. Flowchart alur perancangan radio streaming

Pada flowchart diatas dapat diketahui bahwa penelitian dimulai dengan melakukan identifikasi masalah pada Radio Unas terkait sistem yang digunakan Radio Unas. Dari hasil identikasi ditemukan beberapa masalah yang harus difokuskan menjadi satu permasalahan yang kemudian akan menjadi dasar dalam mengembangkan sistem yang akan dibuat. Selanjutnya studi literatur dilakukan guna mencari referensi topik pembahasan yang berhubungan dengan penelitian penulis, referensi yang digunakan sebagai rujukan pada penelitian ini yang berkaitan dengan sistem radio online, radio streaming yang berbasis web.

Kemudian mulai dilakukan proses Analisis kebutuhan pengguna, perancangan sistem, kemudian dilakukan pengujian. Jika ada kekurangan pada sistem maka akan dilakukan evaluasi dan perbaikan. Namun jika tidak ada yang perlu di evaluasi, kemudian terakhir implementasi. Jika semua sudah berhasil maka dibuatlah sebuah laporan penelitian untuk proses pengembangan dan perbaikan penelitian ini.

\subsection{Perancangan Sistem Radio Streaming}

Arsitektur perancangan sistem radio streaming dengan server icecast digambarkan pada Gambar 3 sebagai berikut:

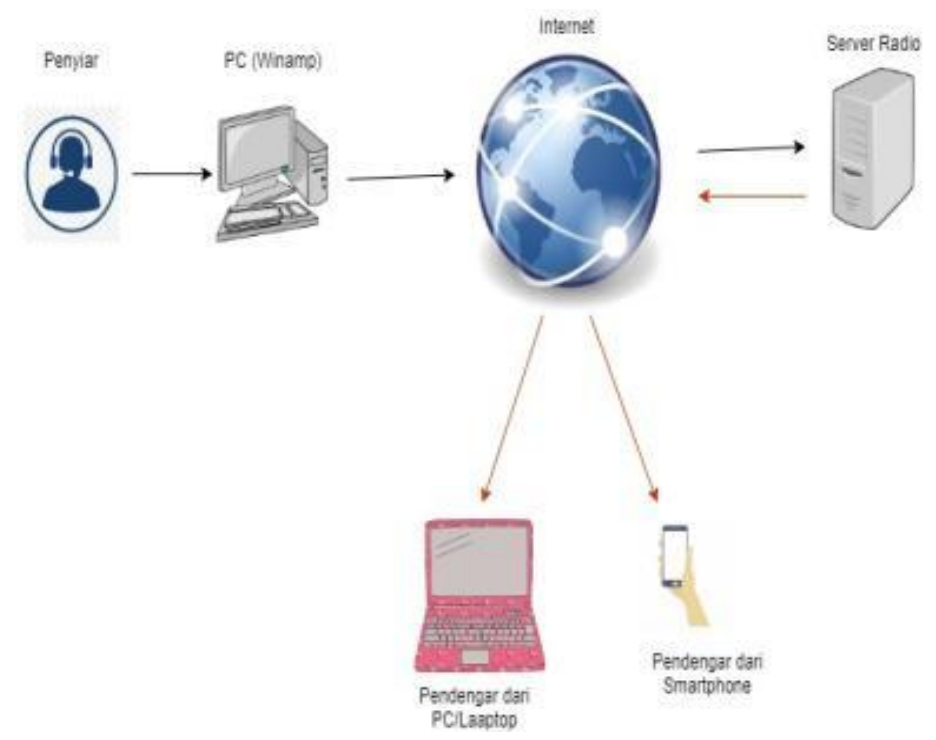

Gambar 3. Arsitektur perancangan sistem radio streaming 
JURNAL MEDIA INFORMATIKA BUDIDARMA

Volume 4, Nomor 3, Juli 2020, Page 715-725

ISSN 2614-5278 (media cetak), ISSN 2548-8368 (media online)

Available Online at https://ejurnal.stmik-budidarma.ac.id/index.php/mib

DOI 10.30865/mib.v4i3.2214

Penjelasan dari gambar 3 bahwa cara kerja radio streaming yaitu ketika server streaming sudah dijalankan melalui software Winamp dan Edcast dari komputer penghubung server. Kemudian penyiar radio melakukan siaran melalui microphone lalu dihubungkan ke server. Suara yang masuk akan diolah dan mengalami proses encoding, lalu terhubung ke server streaming. Kemudian server yang terkoneksi dengan internet akan menyiarkan suara tersebut ke internet sehingga dapat di dengarkan pengguna secara langsung baik lewat komputer ataupun smartphone.

\subsection{Kebutuhan Harware dan Software}

Dalam melakukan penelitian ini diperlukan[13] perangkat keras (hardware) dan perangkat lunak (software) dalam merancancang aplikasi diantaranya sebagai berikut:

1. Perangkat Keras (Hardware)

Tabel di bawah ini merupakanspesifikasi perangkat yang digunakan dalam penelitian ini.

Tabel 1. Spesifikasi Hardware

\begin{tabular}{ll}
\hline Perangkat & Spesisfikasi Perangkat \\
\hline Processor & Processor Intel core i5-5200U 2.7 GHz \\
Memory & DDR 3 8 GB \\
Storage & Hardisk 512 GB \\
VGA & Nvdia Geforce 930 M 4GB \\
OS & Windows 8.1 \\
\hline
\end{tabular}

2. Perangkat Lunak (Software)

Berikut adalah software yang digunakan untuk pembuatan aplikasi ini yaitu:

a. Winamp, Software ini digunakan untuk menginput audio dan setting radio streaming

b. Edcast, sebuah plugin yang digunakan untuk mengirim streaming audio ke server streaming.

c. XAMPP, Software aplikasi yang digunakana sebagai server lokal dalam membuat database MySQL dan untuk pengembangan web berbasis bahasa pemrograman PHP.

d. Sublime Text 3, Sebuah kode editor yang digunakan untuk menulis kode bahasa pemrograman.

e. Google Chrome, Web browser yang digunakan untuk menguji website dan radio streaming.

\section{HASIL DAN PEMBAHASAN}

Pada bab ini akan menjelaskan analisa, hasil serta pembahasan dari radio online Universitas Nasional. Bab ini juga mempresentasikan penjelasan berupa penjelasan interface dari sistem yang telah dibuat. Serta pengujian sistem yang dilakukan dengan blackbox testing yaitu hanya mengamati hasil eksekusi melalui data uji tanpa harus melihat algoritma atau logika dalam sistem.

\subsection{Rancangan Entity Relatioship Diagram}

ERD(Entity Relationship Diagram) merupakan suatu model yang menggunakan susunan data yang disimpan dalam sistem secara abstrak. Berikut adalah Entity Relationship Diagram dari sistem infromasi radio Universitas Nasional yang dapat dilihat pada gambar berikut ini:

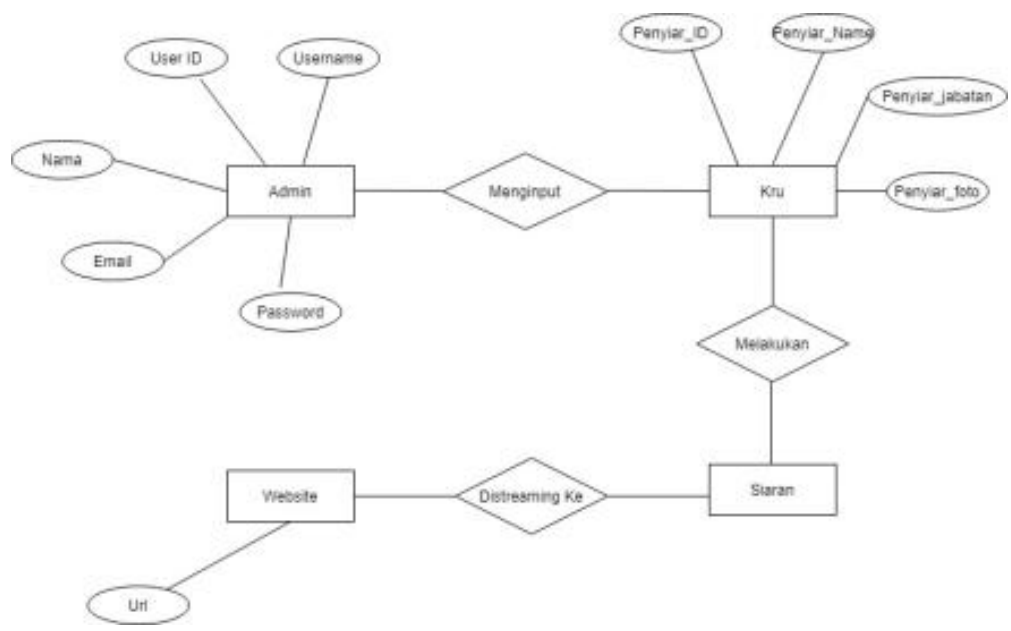

\subsection{Perancangan Activity Diagram}

Gambar 4. Entity Relatioship Diagram

Berikut adalah activity diagram mendengarkan radio streaming Universitas Nasional oleh pengunjung seperti yang di tunjukan pada Gambar 5 dibawah ini. 
ISSN 2614-5278 (media cetak), ISSN 2548-8368 (media online)

Available Online at https://ejurnal.stmik-budidarma.ac.id/index.php/mib DOI 10.30865/mib.v4i3.2214

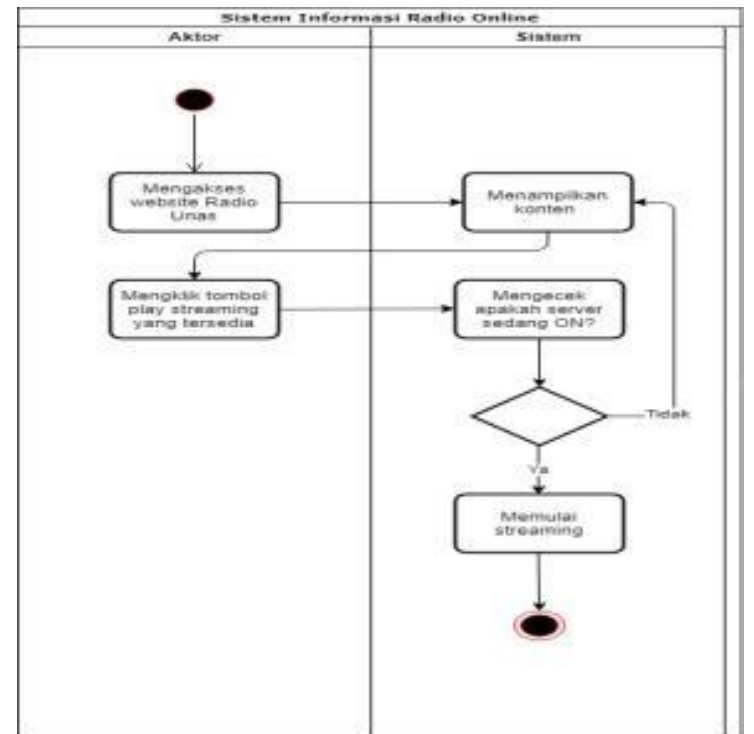

Gambar 5. Activity Diagram Mendengarkan Radio Streaming

\subsection{Implementasi Radio Streaming}

Pada tahap implementasi perancangan web Radio Unas ini yaitu tahap instalasi radio streaming dan pembuatan web pada server lokal. Berikut adalah implementasi streaming Radio Unas. Hal pertama yang dilakukan adalah install software pluign edcast.

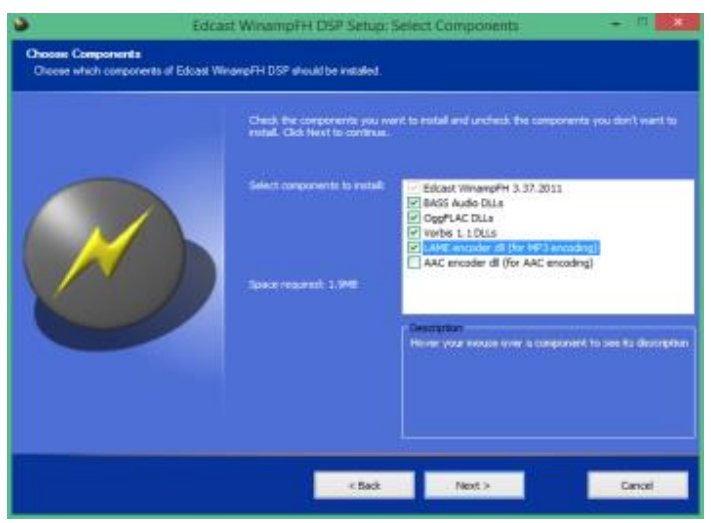

Gambar 6. Instalasi Edcast

Setelah Edcast berhasil terinstall, klik tombol Add Encoder untuk membuat encoder baru. Tampilan edcast yang pertama muncul sebelum membuat encoder baru dan melakukan pengaturan adalahsebagai berikut.

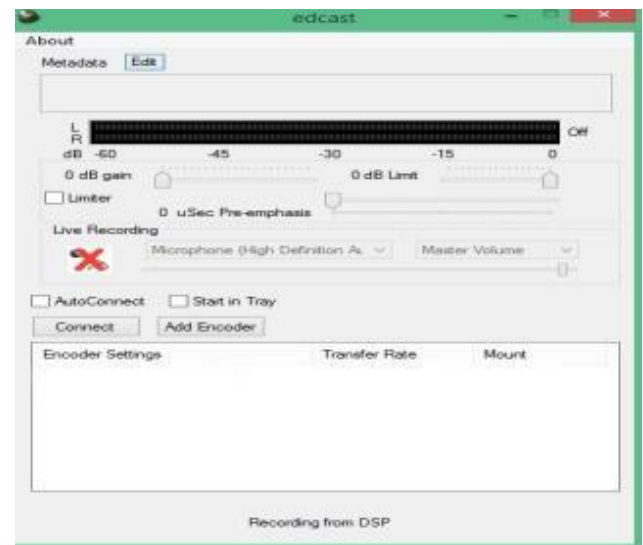

Gambar 7. Aplikasi Edcast

Apabila telah menambahkan encoder, selanjutnya melakukan pengaturan pada encoder yang akan digunakan. Pada tahap pengaturan harus diatur sesuai kebutuhan kita, seperti untuk mengirim dan menghasilkan suara yang bagus maka bitrate harus semakin tinggi, tetapi jika koneksi jaringan internet lemah maka akan menghasilkan 
JURNAL MEDIA INFORMATIKA BUDIDARMA

Volume 4, Nomor 3, Juli 2020, Page 715-725

ISSN 2614-5278 (media cetak), ISSN 2548-8368 (media online)

Available Online at https://ejurnal.stmik-budidarma.ac.id/index.php/mib

DOI 10.30865/mib.v4i3.2214

suara yang terputus-putus. Sedangkan untuk mengatu IP server, Port server, dan password itu telah ditentukan oleh penyedia hosting server radio streaming. Disini penulis memakai caster.fm sebagai server radio streaming.

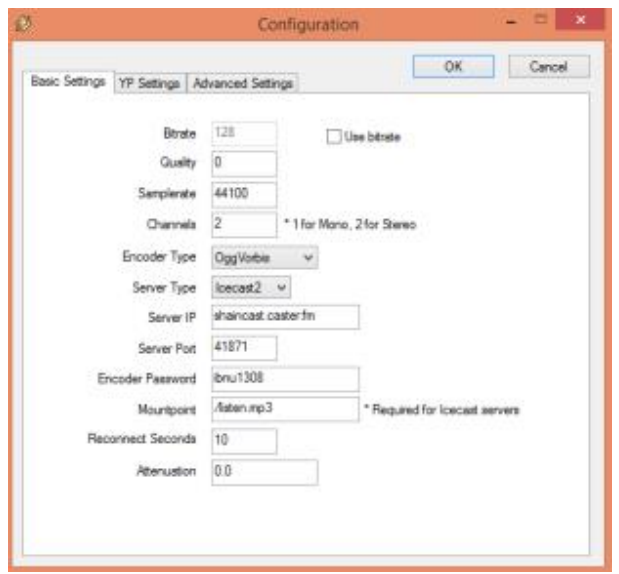

Gambar 8. Konfigurasi Basic setting

Setelah melakukan pengaturan pada basic setting selanjutnya melakukan pengaturan pada YP setting. Pada YP setting penulis mengisikan indentitas dari Radio Unas.

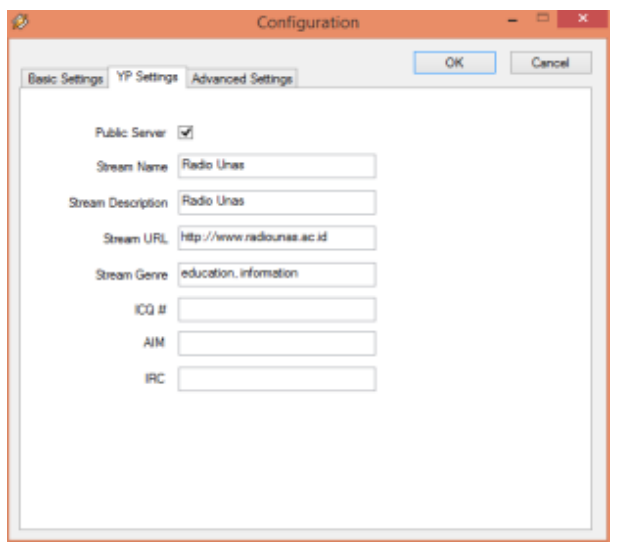

Gambar 9. YP setting

Kemudian melakukan pengaturan pada Advence setting. Pada Advence setting kita bisa merekam suara saat streaming dan bisa mendengarkan hasil rekamannya apabila dibutuhkan nanti.

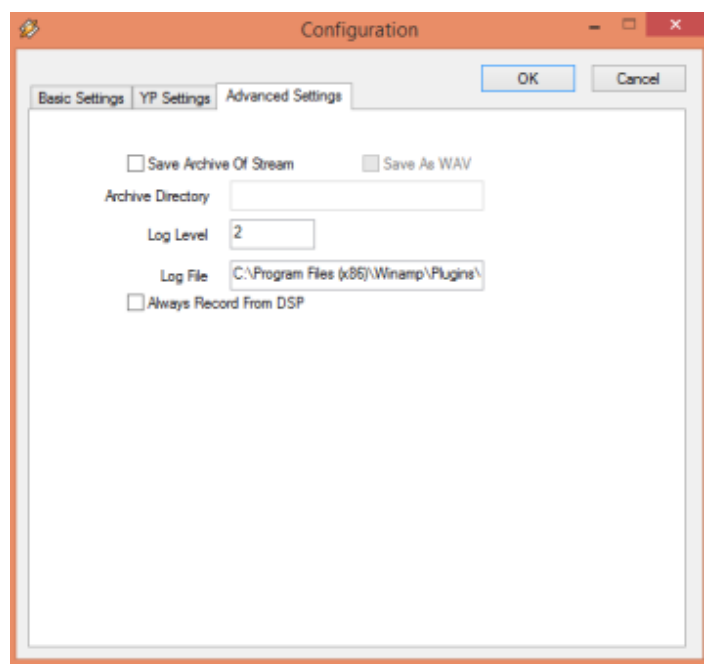

Gambar 10. Advence setting 
JURNAL MEDIA INFORMATIKA BUDIDARMA

Volume 4, Nomor 3, Juli 2020, Page 715-725

ISSN 2614-5278 (media cetak), ISSN 2548-8368 (media online)

Available Online at https://ejurnal.stmik-budidarma.ac.id/index.php/mib

DOI 10.30865/mib.v4i3.2214

Setelah menyelesaikan semua setting dan terkoneksi dengan internet serta penginputan suara telah aktif dan muncul angka transfer rate 54 kbps seperti pada gambar 10 sebagai tanda bahwa edcast sedang mengirimkan data suara yang kemudian dapat didengar para pengguna Radio Unas melalui siaran streaming.

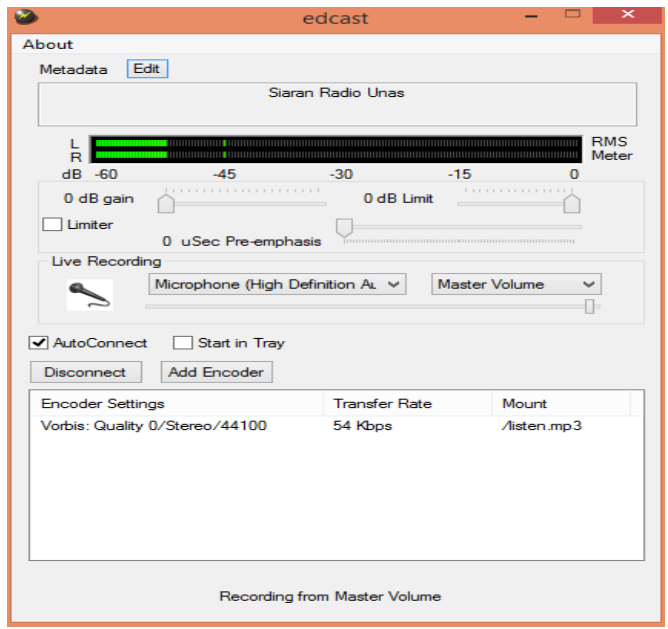

Gambar 11. YP setting

Untuk menguji akses streaming Radio Unas dengan cara membuka web server radio streaming yaitu caster.fm yang memberikan flash palyer secara gratis. Selanjutnya memutar lagu lewat winamp atau melakukan siaran dengan microphone.
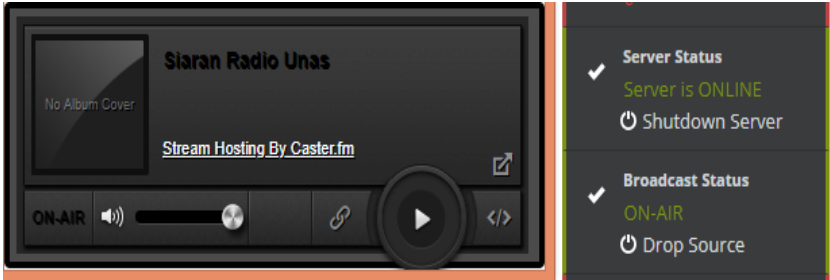

Gambar 12. Server Radio Caster.fm

Dan hasil pengujiannya siaran langsung dan pemutaran lagu lewat radio bisa didengarkan pendengar melalui akses internet dengan memakai winamp sebagai audio player.

\subsection{Implementasi Website}

Pada implementasi kali ini peneliti akan menjelaskan hasil dari website radio online Universitas Nasional yang telah dibuat dengan menampilkan interface sistem. Pengujian sistem dilakukan menggunakan blckbox testing. Berikut adalah tampilan dari sistem Radio online Universitas Nasional.

\section{a. Tampilan Login Admin}

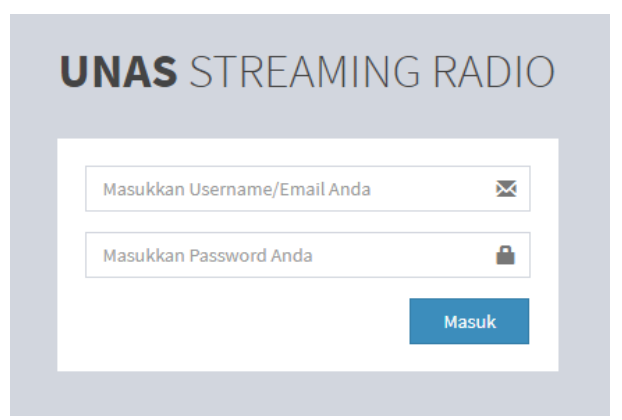

Gambar 13. Login admin

Halaman login admin ini merupakan halaman yang berfungsi untuk mengelola isi dari website Radio Unas. Hanya admin yang mempunyai hak akses mengenai pengelolaan website Radio Unas yang bisa mengoperasikan halaman administrator.

\section{b. Tampilan Halaman Beranda}

Beranda adalah halaman yang pertama kali muncul saat pengunjung membuka website dan ingin mendengarkan siaran radio streaming. Pada website terdapat menu beranda, jadwal siaran berita, galeri, tentang kami, dan kru. 
ISSN 2614-5278 (media cetak), ISSN 2548-8368 (media online)

Available Online at https://ejurnal.stmik-budidarma.ac.id/index.php/mib

DOI 10.30865/mib.v4i3.2214
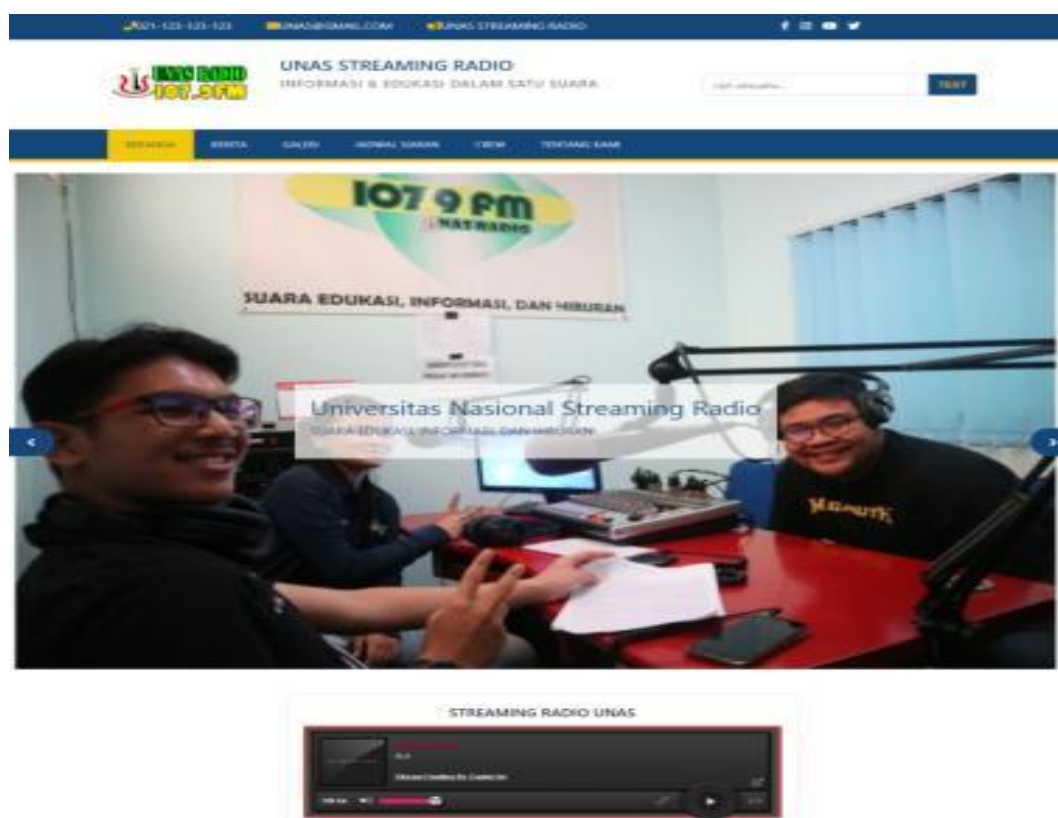

Gambar 14. Tampilan Beranda

\section{c. Tampilan Halaman Galeri}

Pada menu galeri yang digunakan untuk menyimpan dokumentasi sehingga pengunjung bisa melihat kegiatan apa saja yang dilakukan radio Universitas Nasional.
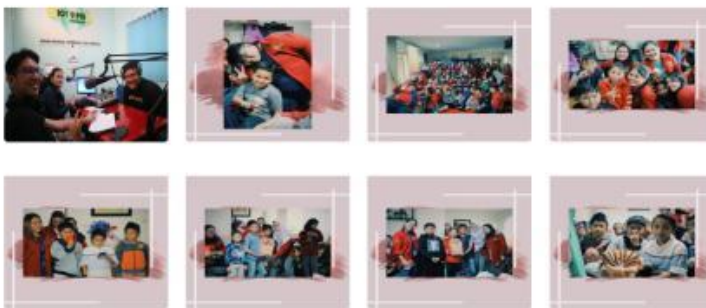

Gambar 15. Galeri

\section{d. Tampilan Konten Radio Streaming}

Pada gambar 5 adalah tampilan dari konten radio streaming universitas nasional. Untuk mendengarkan siaran pengunjung website hanya perlu mengklik button play pada tampilan radio streaming. Apabila radio unas sedang tidak melakukan siaran langung maka akan pengunjung akan mendengarkan auto playlist lagu yang sudah di setting oleh admin.

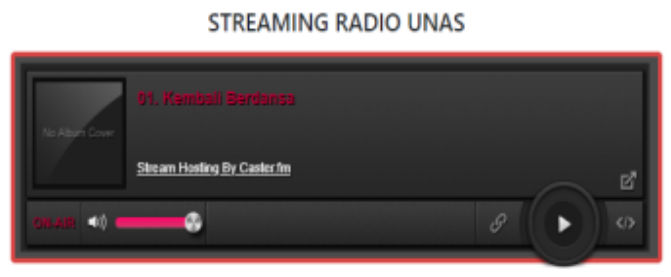

Gambar 16. Konten radio streaming

\section{e. Tampilan Halaman Berita}

Halaman berita terkini mengenai kegiatan apa saja yang dilakukan radio Universitas Nasional mulai dari seminar, pelatihan, dan lainnya. 

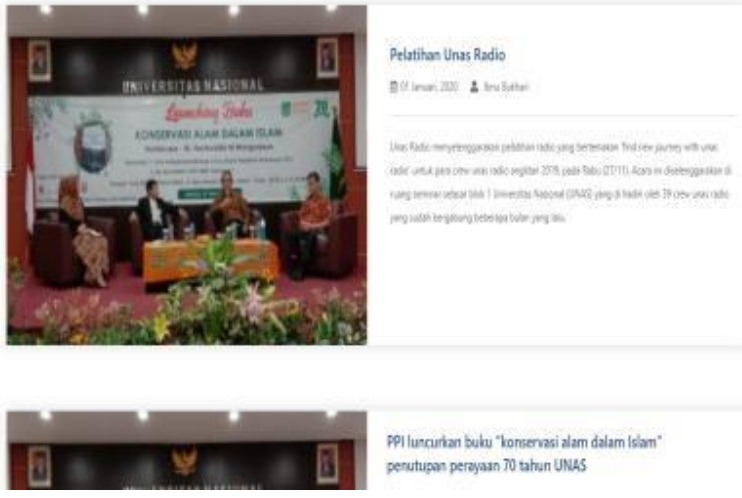

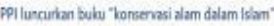
serutugam pergyann 70 tatun UNas

Gambar 17. Berita

\subsubsection{Tampilan Halaman Crew}

Pada menu crew, pengunjung bisa melihat struktur organisasi yang ada di radio Universitas Nasional.

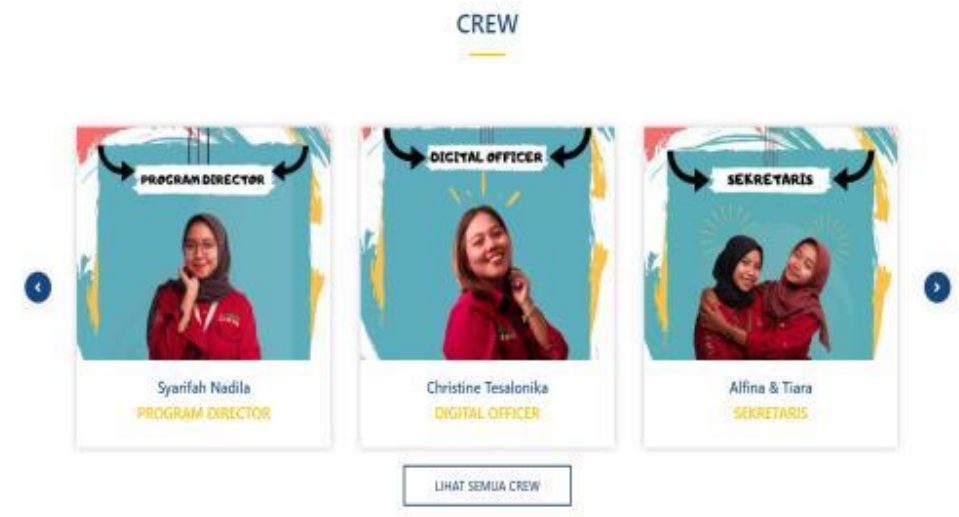

Gambar 18. Crew Radio Unas

Demikian lah beberapa gambaran dari tampilan implemnetasi perancangan sistem informasi Radio Online Universitas Nasional.

\subsection{Pengujian Radio Streaming}

Pengujian sistem diakukan dengan menggunakan blackbox yang bertujuan untuk mencari dan mengidentifikasi kesalahan pada sistem. Berikut adalah pengujian sistem pada radio streaming.

Tabel 2. Pengujian radio streaming

No. Komponen yang $\quad$ Diuji $\quad$ Skenario Uji $\quad$ Hasil yang Diharapkan $\quad$ Hasil

\begin{tabular}{|c|c|c|c|c|}
\hline 1 & Connect Edcast & $\begin{array}{l}\text { Mengatur koneksi } \\
\text { Edcast }\end{array}$ & $\begin{array}{c}\text { Ketika pengaturan telah selesai dan tombol } \\
\text { connect di klik, maka koneksi telah } \\
\text { terhubung }\end{array}$ & Valid \\
\hline 2 & Server Caster.fm & $\begin{array}{l}\text { Membuka link server } \\
\text { Caster.fm }\end{array}$ & $\begin{array}{c}\text { Server Caster.fm akan terkoneksi dengan } \\
\text { Edcast }\end{array}$ & Valid \\
\hline 3 & Input file audio & $\begin{array}{l}\text { Memutar lagu dari } \\
\text { winamp }\end{array}$ & $\begin{array}{c}\text { Lagu dapat didengar melalui radio } \\
\text { streaming }\end{array}$ & Valid \\
\hline 4 & Input suara & $\begin{array}{l}\text { Menghubungkan mic } \\
\text { audio ke komputer }\end{array}$ & $\begin{array}{c}\text { Siaran dapat didengar melalui radio } \\
\text { streaming }\end{array}$ & Valid \\
\hline
\end{tabular}

\subsection{Pengujian Delay Radio Steraming}

Delay merupakan waktu tunda yang dibutuhkan data untuk menempuh jarak dari asal ke tujuan. Delay diakibatkan oleh jarak media dan juga waktu proses yang lama. 
Tabel 3. Standar Kulitas delay berdasarkan ITU-T G.114

\begin{tabular}{ll}
\hline Kategori & Besaran Delay \\
\hline Sangat Baik & $<150 \mathrm{~ms}$ \\
Baik & $150 \mathrm{~ms} \mathrm{~s} / \mathrm{d} \mathrm{300} \mathrm{ms}$ \\
Buruk & $300 \mathrm{~ms} \mathrm{~s} / \mathrm{d} 450 \mathrm{~ms}$ \\
Sangat Buruk & $>450 \mathrm{~ms}$ \\
\hline
\end{tabular}

Berikut ini adalah hasil pengukuran delay dari radio streaming Universitas Nasional menggunakan server Icecast dengan konfigurasi streaming encoder yang berbeda-beda, yaitu 32Kbps, $48 \mathrm{Kbps}, 96 \mathrm{Kbps}$, dan $128 \mathrm{Kbps}$. Hasil pengamatan dari nilai rata-rata delay seperti yang ditunjukan pada Tabel 4.

Tabel 4. Rata-rata delay pada radio streaming server Icecast

\begin{tabular}{ll}
\hline Pengaturan Encoder & Delay \\
\hline MP3 32 Kbps, 22.050kHz & $39,2 \mathrm{~ms}$ \\
MP3 48 Kbps, 22.050kHz & $36,4 \mathrm{~ms}$ \\
MP3 96 Kbps, 44.100kHz & $32,1 \mathrm{~ms}$ \\
MP3 128 Kbps, 44.100kHz & $28 \mathrm{~ms}$ \\
\hline
\end{tabular}

Beradasarkan hasil pengukuran delay radio streaming Universitas Nasional menggunakan server Icecast dengan konfigurasi streaming encoder $32 \mathrm{Kbps}, 48 \mathrm{Kbps}, 96 \mathrm{Kbps}$, dan $128 \mathrm{Kbps}$ delay maksimal yang terjadi yaitu sebesar 39,2 ms. Dengan nilai delay sebesar itu artinya layanan radio Streaming Universitas Nasional menggunakan server icecast masih memenuhi standar kualitas delay G.114 ITU-T yang menunjukkan nilai delay dibawah $150 \mathrm{~ms}$ itu adalah kualitas yang sangat baik untuk radio streaming Universitas Nasional.

\section{KESIMPULAN}

Berdasarkan hasil penelitian, pengujian, dan implementasi pada Sistem Informasi Radio Online Universitas Nasional, maka dapat di simpulkankan sebagai berikut:

1. Sistem informasi radio online bekerja melalui jaringan internet sehingga mampu menjangkau wilayah dimana saja dengan syarat terkoneksi dengan jaringan internet.

2. Sistem informasi Radio Streaming ini dapat membantu mahasiswa Universitas Nasional dan juga masyarakat untuk mendengarkan Radio Streaming, mendengarkan music, mengunjungi web streaming, menampilkan galeri, menampilkan berita, dan menampilkan crew atau struktur organisasi dari Radio Unas.

3. Memberikan sarana media informasi, edukasi dan hiburan dalam bentuk website dengan konten radio streaming.

\section{REFERENCES}

[1] Audi, M., Rokhmawati, R. I., \& Az-Zahra, H. M. "Analisis Aspek Usability dan User Experience Website dan Aplikasi Mobile Radio Streaming (Studi Pada Website dan Aplikasi Mobile Radio Prambors)”, Jurnal Pengembangan Teknologi Informasi dan Ilmu Komputer e-ISSN, 2548, 964X. 2018.

[2] Harjanti, T. W., \& Sutendi, T. "Perancangan Dan Implementasi Radio Streaming Berbasis Android Pada Komunitas Devilzcode”, Konferensi Nasional Ilmu Pengetahuan dan Teknologi, Vol. 1 (1), Agustus 2016.

[3] Nugroho, A. S. B., Warediah, I., Ilmi, M. K., "Aplikasi Radio Daring Pemerintah Kabupaten Hulu Sungai Tengah Berbasis Web", Jurnal POROS TEKNIK Volume 10, No. 1, Juni 2018.

[4] Nasikin, N., Rohman, Z., \& Hakim, A. R., "Optimalisasi Live Audio Streaming Shoutcast Dnas Server Dengan Metode Qos Di Lingkungan Radio Komunitas Kampus Polnesia”, SAKTI (Seminar Ilmu Komputer dan Teknologi Informasi Vol. 3, No. 1, pp. 14-21. 2018.

[5] Sungkar, M. S., \& Taofik, I., "Web Server Live Radio Streaming Untuk Media Informasi Kegiatan Belajar Mengajar", Jurnal ICT: Information Communication \& Technology, Vol 17(1), 6-10. 2018.

[6] Asy'ari, N. A. S., \& Muriyatmoko, D., "Usability Testing for Android Radio Streaming Apps of Songgolangit FM". IOP Conf. Series: Journal of Physics: Conf. Series 1471, 2020.

[7] Maulina. F. S., "Pengembangan Aplikasi Radio Streaming Dan On-Demand Berbasis Website Di Radio Suara Bangkalan Fm", Jurnal Manajemen Informatika. Volume 9, No. 02, Tahun 2019.

[8] Basyah, B. L., Hustinawati, H., \& Adesita, E., "Rancang Bangun Aplikasi Radio Online Berbasis Web", Jurnal Ilmiah Fifo, Vol 7, No. 2, 167-178. 2015.

[9] Al Ayubi, A., Kurniawan, D., \& Febriansyah, F. E., 'Rancang Bangun Aplikasi Radio Streaming Dengan Menggunakan Shoutcast Distributed Network Audio Server (DNAS), Jurnal Komputasi, Vol 4 (1), 2016.

[10] Wei, C., \& Zhang, H. “Applications of a Streaming Video Server in a mobile phone live streaming system”. Journal of Software Engineering and Applications, Vol 7 (12), 975, 2015.

[11] Muriyatmoko, D., Asy'ari, N. A. S., \& Arif, M. S., "Android Radio Streaming Apps for Songgolangit FM Ponorogo". In Journal of Physics: Conference Series, Vol. 1381, No. 1, p. 012017, 2019.

[12] Saputra, Z. R., "Shoutcast Distributed Network Audio Server (DNAS) Sebagai Server Streaming Radio Kampus", Jurnal Sigmata Volume 5, No.1 Maret 2017. 
JURNAL MEDIA INFORMATIKA BUDIDARMA

Volume 4, Nomor 3, Juli 2020, Page 715-725

ISSN 2614-5278 (media cetak), ISSN 2548-8368 (media online)

Available Online at https://ejurnal.stmik-budidarma.ac.id/index.php/mib

DOI 10.30865/mib.v4i3.2214

[13] Ramadhana, A., Roza, E., \& Irfan, I., "Perancangan Website dengan Inovasi Konten Radio Streaming FISIP UHAMKA", In Prosiding Seminar Nasional Teknoka Vol. 1, pp. 14-22. 2016. 